\title{
Early Immunological Response to German Cockroach Frass Exposure Induces a Th2/Th17 Environment
}

\author{
Kristen Page ${ }^{a, c}$ Ping Zhou ${ }^{a}$ John R. Ledford ${ }^{a}$ Scottie B. Day ${ }^{a}$ Riad Lutfi ${ }^{a}$ \\ Krista Dienger $^{b}$ lan P. Lewkowich ${ }^{b}$ \\ Divisions of a Critical Care Medicine and ${ }^{b}$ Immunobiology, Cincinnati Children's Hospital Medical Center \\ and Cincinnati Children's Research Foundation, and 'Department of Pediatrics, University of Cincinnati, \\ Cincinnati, Ohio, USA
}

\section{Key Words \\ Chemokines $\cdot$ Cytokines $\cdot$ Immune response $\cdot$ Pathogen associated-molecular patterns $\cdot$ Toll-like receptor • \\ Dendritic cell $\cdot$ Airway inflammation $\cdot$ Cockroach}

\begin{abstract}
Cockroach exposure is a major risk factor for the development of asthma; however, the early immune events induced by cockroach leading to the Th2 response are not fully understood. Exposure of naïve mice to German cockroach (GC) feces (frass) was sufficient to induce dendritic cell (DC) recruiting and activating chemokines C-C motif ligand 20, granulocyte macrophage colony-stimulating factor, granulocyte colony-stimulating factor and macrophage inflammatory protein-1 $\alpha$ into the airways. This corresponded with an increase in myeloid DCs ( $\mathrm{mDCs}$ ) in the airways as well as increased expression of CD80 and CD86 on the mDCs. Plasmacytoid DCs in the lung were unchanged. Levels of IL-5, IL-17A and IL-6 cytokines in whole lung cultures were significantly increased $18 \mathrm{~h}$ following GC frass exposure demonstrating the early development of a mixed Th2/Th17 response. In addition, GC frass stimulated the production of IL-23, IL-6 and IL-12p70 from bone marrow-derived mDCs. Adoptive transfer of GC frass-pulsed mDCs induced airway
\end{abstract}

reactivity, airway inflammation as well as eosinophilia and induced a strong Th2/Th17 response in the lung. MyD88-deficient bone marrow-derived mDCs did not respond to GC frass treatment, suggesting a functional Toll-like receptor pathway was important to induce the Th2/Th17 response. Together, our data show that GC frass activated the innate immune response to augment DC recruitment and activation of $\mathrm{mDCs}$ which promoted robust T cell-skewing cytokines and ultimately drive the development of airway inflammation.

Copyright $\odot 2010$ S. Karger AG, Basel

\section{Introduction}

Asthma is a chronic inflammatory condition of the airways, characterized by airway hyperresponsiveness (AHR), persistent airway inflammation, increased mucus production and airway remodeling. It is accepted that asthma results from an inappropriate Th2-dominated immune response. One of the more potent allergens thought to be a risk factor for the development of asthma is cockroach. Many studies have shown a correlation with the levels of cockroach allergen and the severity of asthma [1-4]. We recently confirmed that airway administra- 
tion of German cockroach (GC) feces (frass), the likely sensitizing agent, induced a Th2 response leading to allergic airway inflammation and reactivity in a mouse model [5]. GC frass is complex and contains a number of early innate immune response activators, including endotoxin, a Toll-like receptor (TLR) 4 agonist, a TLR2 agonist [6] and active serine proteases which activate protease-activated receptor-2 [7]. However, the early events that facilitate the development of the pathogenic Th2 response following initial exposure to GC frass are currently unclear.

Dendritic cells (DCs) are the most potent antigen-presenting cells and are thought to bridge innate and adaptive immunity. Mucosal DCs form a dense network associated with the airway epithelium and can form long extensions into the airway lumen [8]. While some immature DCs are normally associated with the epithelial cell layers, DCs are also recruited to the airways via the release of chemokines, including macrophage inflammatory protein (MIP)-3 $\alpha$ (also known as CCL20) and MIP$1 \alpha$. CCL20 is the only known ligand for the CCR6 receptor expressed on immature myeloid DCs at the mucosal surface [9]. There is considerable data confirming the role for CCL20 in DC recruitment, including studies which showed CCL20 promoted DC recruitment into the airways following allergen challenge in mice [10] and humans [11]. Proliferation of DCs may occur by the expression of granulocyte macrophage colony-stimulating factor (GM-CSF). Intranasal exposure to house dust mite (HDM) induced GM-CSF release and administration of anti-GM-CSF neutralizing antibody decreased airway inflammation [12]. Two sets of DCs, myeloid (mDCs) and plasmacytoid (pDCs) have been identified in humans and mice. mDCs (also called type 1 DCs) express CD13 and CD33 markers, require GM-CSF for their survival and produce high levels of IL-12 $[13,14]$. On the other hand, pDC (also called type 2 DC) lack myeloid cell markers and express high amounts of IL-3 receptor $\alpha$-chain (CD123), which is required for their survival and maturation and they secrete high levels of type I interferon [15, 16]. $\mathrm{pDCs}$ have been shown to be protective against the development of asthma [17]. We have previously demonstrated that the ratio of $\mathrm{mDC} / \mathrm{pDC}$ may play a role in the development of allergic asthma in mouse models [18]. In fact, an asthma-susceptible strain (A/J) was found to have higher $\mathrm{mDC} / \mathrm{pDC}$ ratios compared to a resistant strain $(\mathrm{C} 3 \mathrm{H})$. This suggests an important role for different subtypes of DCs in the lung that encounter allergens.

A crucial role for the DCs in mediating allergic airway disease is their ability to synthesize and release many of the cytokines involved in T cell differentiation. IL- 6 can drive the differentiation and expansion of Th2 cells [19], while IL- 6 in the presence of tumor growth factor- $\beta$ and IL-23 can induce Th17 cells $[20,21]$. IL-12p70 has been shown to skew Th0 cells towards Th1 [22] and this shift has been shown to induce allergen tolerance. IL-4 is able to differentiate Th0 cells into Th2 cells which are known to be important in asthma. A recently identified Th subtype, Th17, has also been implicated in asthma [23, 24]. We recently showed that pulmonary $\mathrm{mDCs}$ played a crucial role in the induction of AHR in asthma-susceptible mice in part through their ability to induce IL-23 production [18]. Thus, we hypothesize that the early events in the development of a Th2/Th17 response occur through the reprogramming of DCs by GC frass. Our objective was to determine the role of GC frass on the recruitment and activation of DCs which would ultimately lead to the development of the asthma phenotype, and to investigate the role of innate immune receptors on regulating this process. Our findings suggest that a single exposure to GC frass can activate resident airway cells to induce the release of DC-recruiting chemokines leading to the preferential increase in mDCs. GC frass can also directly stimulate DCs to release Th17-promoting cytokines, and induce resident lung cells to release Th2-skewing cytokines. In addition, GC frass-stimulated mDCs administered via the airways were sufficient to induce airway inflammation. Importantly, it appears that a functional TLR signaling pathway is required to induce $\mathrm{mDC}$ cytokine release as MyD88-deficient bone marrow-derived DCs (BMDCs) fail to synthesize IL-6 or IL-23 following GC frass exposure. Our data clearly suggest an early immune response to allergen challenge leading to preferential increases in $\mathrm{mDC}$ and a Th2/Th17 milieu in the lung within the first $24 \mathrm{~h}$ following a single $\mathrm{GC}$ frass exposure.

\section{Materials and Methods}

Cockroach Frass

Fecal remnants (frass) from GC were resuspended in endotoxin-free double-distilled water $\left(2 \mathrm{~h}\right.$ at $4^{\circ} \mathrm{C}$ while rocking) and frozen in aliquots for use throughout the entire study. Extracts were centrifuged to remove debris $\left(13,000 \mathrm{~g}\right.$ for $5 \mathrm{~min}$ at $\left.4^{\circ} \mathrm{C}\right)$, supernatants were harvested and total protein was measured using the Bio-Rad Protein Assay Dye (Bio-Rad, Hercules, Calif., USA).

Animals

Six-week-old female Balb/c, C57Bl/6 (Jackson Laboratory, Bar Harbor, Me., USA) and MyD88-deficient mice (S. Akira) [25] were housed in a laminar hood in a pathogen-free animal facility. The MyD88-deficient mice were fed Teklad Global 18\% protein rodent 
diet with 4,100 ppm of the medication Uniprim added (Harlan, Indianapolis, Ind., USA). Animal care was provided in accordance with NIH guidelines. These studies were approved by the Cincinnati Children's Hospital Medical Center Institutional Animal Care and Use Committee.

\section{GC Frass Exposure}

Mice (8 per group) were anesthetized with ketamine (45 mg/ $\mathrm{kg}) /$ xylazine $(8 \mathrm{mg} / \mathrm{kg}$ ) prior to phosphate-buffered saline (PBS; $40 \mu \mathrm{l})$ or GC frass $(40 \mu \mathrm{g} / 40 \mu \mathrm{l})$ exposure by an intratracheal instillation as previously described (fig. 1a) [26]. Mice were given a lethal dose of sodium pentobarbital $18 \mathrm{~h}$ later and lungs were lavaged with Hank's balanced salt solution without calcium or magnesium (Invitrogen, Carlsbad, Calif., USA). The lavage fluid was centrifuged $\left(300 \mathrm{~g}\right.$ for $10 \mathrm{~min}$ at $4^{\circ} \mathrm{C}$ ); the supernatant was removed for cytokine analysis and immediately stored at $-80^{\circ} \mathrm{C}$. Lungs were isolated $18 \mathrm{~h}$ following a single instillation and wholelung cell culture was performed. In separate experiments, mice were administered a single intratracheal instillation of PBS or GC frass and $24 \mathrm{~h}$ later, lungs were isolated for flow cytometry (fig. 1b).

\section{Flow Cytometry}

Following exposure, whole lungs were placed in RPMI 1640 containing Liberase CI ( $0.5 \mathrm{mg} / \mathrm{ml}$; Roche Diagnostics, Indianapolis, Ind., USA) and DNase I (0.5 mg/ml; Sigma, St. Louis, Mo., USA) at $37^{\circ} \mathrm{C}$ for $45 \mathrm{~min}$. The tissue was forced through a $70-\mathrm{mi}-$ cron cell strainer, and red blood cells were lysed with ACK lysis buffer (Invitrogen). Cells were washed with RPMI containing $10 \%$ fetal bovine serum (FBS), counted and $5 \times 10^{5}$ cells were used for staining. Staining reactions were performed at $4^{\circ} \mathrm{C}$ following incubation with Fc block (monoclonal antibody 2.4G2) for 30 min. Myeloid DCs $\left(\mathrm{CD}_{11 \mathrm{c}^{+}}, \mathrm{CD}_{11 b^{+}}, \mathrm{Gr} 1^{\text {neg }}, \mathrm{CD} 317^{\text {neg }}\right)$ and plasmacytoid DCs $\left(\mathrm{CD} 11 \mathrm{c}^{+}, \mathrm{CD} 11 \mathrm{~b}^{\text {neg }}, \mathrm{Gr} 1^{\text {low }}, \mathrm{CD} 317^{+}\right)$were quantified using anti-CD11c-APC (HL3), anti-CD11b-PE-Cy7 (M1/70) and anti GR-1-APC-Cy7 (RB6-8C5). Co-stimulatory molecule expression was examined using PE-conjugated monoclonal antibodies to CD86 (GL1) and CD80 (16-10A1). Dead cells were excluded using 7-AAD. All antibodies were purchased from eBioscience (San Diego, Calif., USA). Data were acquired with an LSRII flow cytometer (BD Biosciences, San Jose, Calif., USA). Spectral overlap was compensated using the FACSDiVa software (BD Biosciences) and analyzed using FlowJo software (Treestar Inc., Ashland, Oreg., USA).

\section{Isolation and Development of Mature, GC Frass-Pulsed} $B M D C$

Mice were given a lethal dose of sodium pentobarbital prior to removal of tibias and femurs. Bone marrow cells $\left(1.5 \times 10^{7}\right.$ cells per $\mathrm{ml}$ ) were cultured on complete RPMI supplemented with GMCSF (10 ng/ml; Peprotech, Rocky Hills, N.J., USA). Fresh media was added along with GM-CSF $(10 \mathrm{ng} / \mathrm{ml})$ on day 3 . On day 6 , cells were washed, counted and plated $\left(1 \times 10^{6}\right.$ cells $\left./ \mathrm{ml}\right)$ for experimentation. Cells were then treated with endotoxin-free PBS or GC frass $(1 \mu \mathrm{g} / \mathrm{ml})$ for $18 \mathrm{~h}$. Cytokine levels were measured following clarification of the cell culture media $\left(13,000 \mathrm{~g}\right.$ for $5 \mathrm{~min}$ at $\left.4^{\circ} \mathrm{C}\right)$.

\section{Adoptive Transfer of BMDC}

BMDC cultures were grown as indicated above. On day 6, cells were treated with endotoxin-free PBS or GC frass $(1 \mu \mathrm{g} / \mathrm{ml})$ for
$18 \mathrm{~h}$. Cells were washed, counted and resuspended at $2.5 \times 10^{6}$ cells $/ \mathrm{ml}$. Forty microliter of BMDC suspension $\left(1 \times 10^{6}\right.$ cells $)$ was administered to anesthetized mice. Fourteen days later, mice were exposed to either PBS $(40 \mu \mathrm{l})$ or GC frass $(40 \mu \mathrm{g} / 40 \mu \mathrm{l})$. Three days later, airway responses were measured (fig. 1c).

\section{Assessment of Allergic Airway Inflammation}

Allergen-induced AHR was determined as previously described [27]. Briefly, mice were anesthetized $72 \mathrm{~h}$ after the last GC frass exposure, intubated and ventilated at a rate of 120 breaths per minute with a constant tidal volume of air $(0.2 \mathrm{ml})$ using a low-dead-space ventilatory system [28], and paralyzed with decamethonium bromide $(25 \mathrm{mg} / \mathrm{kg})$. After establishment of a stable airway pressure, $25 \mu \mathrm{g} / \mathrm{kg}$ weight of acetylcholine was injected intravenously and dynamic airway pressure (airway pressure time index in $\mathrm{cm} \mathrm{H}_{2} \mathrm{O} \times \mathrm{s}^{-1}$ ) was followed for $5 \mathrm{~min}$. Lungs were lavaged with $1 \mathrm{ml}$ of Hank's balanced salt solution without calcium or magnesium. The lavage fluid was centrifuged $(300 \mathrm{~g}$ for $10 \mathrm{~min}$ at $4^{\circ} \mathrm{C}$ ); the supernatant was removed for cytokine analysis and immediately stored at $-80^{\circ} \mathrm{C}$. Cells were resuspended in $1 \mathrm{ml}$ PBS containing $10 \% \mathrm{FBS}$, and total cell numbers were counted on a hemocytometer. Bronchoalveolar liquid (BAL) cells were centrifuged (64 $g$ for $5 \mathrm{~min}$ at room temperature) onto a microscope slide using Cytospin II (Shandon Thermo, Waltham, Mass., USA). Slides were subsequently stained with Diff-Quick (Thermo Electron Corporation, Pittsburg, Pa., USA) solution for differential cell counting. BAL fluid was stored at $-80^{\circ} \mathrm{C}$ for cytokine analysis.

\section{Total Lung Cell Homogenate Culture}

Whole lungs were isolated from mice, minced and placed in RPMI 1640 containing Liberase CI $(0.5 \mathrm{mg} / \mathrm{ml}$; Roche Diagnostics) and DNase I ( $0.5 \mathrm{mg} / \mathrm{ml}$; Sigma) at $37^{\circ} \mathrm{C}$ for $45 \mathrm{~min}$. The tissue was forced through a 70-micron cell strainer, and red blood cells were lysed with ACK lysis buffer (Invitrogen). Cells were washed with RPMI containing $10 \%$ FBS, counted and plated (250,000 cells per well in $300 \mu \mathrm{l}$ final volume) in a 96-well plate. In some cases, cells were incubated at $37^{\circ} \mathrm{C}$ in $5 \% \mathrm{CO}_{2}$ incubator for $18 \mathrm{~h}$ at which time cell supernatants were removed, clarified and stored at $-80^{\circ} \mathrm{C}$ for ELISA. In other cases, these cells were stained for flow cytometry.

\section{Histology}

Whole lungs were removed and formalin fixed. Lungs were embedded in paraffin, sectioned and stained with hematoxylin and eosin and periodic acid Schiff (PAS).

\section{ELISA}

ELISA kits for CCL20, MIP-1 $\alpha$, GM-CSF, granulocyte colonystimulating factor (G-CSF), IL-6, IL-10, IL-12p70, IL-17A and IFN- $\gamma$ were purchased from R\&D Systems (Minneapolis, Minn., USA) and used according to the manufacturers' specifications.

\section{Statistical Analysis}

When applicable, statistical significance was assessed by oneway analysis of variance (ANOVA). Differences identified by ANOVA were pinpointed by Student-Newman-Keuls' multiple range test. 
Fig. 1. Mouse exposure protocols. a Mice were exposed to a single intratracheal (i.t.) instillation of PBS $(40 \mu \mathrm{l})$ or GC frass $(40 \mu \mathrm{g} / 40 \mu \mathrm{l})$ and BAL fluid was harvested $18 \mathrm{~h}$ later. Lungs were isolated and cultured for an additional $24 \mathrm{~h}$ in the absence of additional stimulation. b Mice were exposed to a single intratracheal instillation and lungs were harvested $24 \mathrm{~h}$ later for analysis by flow cytometry. c PBS- or GC frasspulsed BMDC were instilled intratracheally at day $0 ; 14$ days later, mice received an intratracheal instillation of either PBS or GC frass. On day 17, airway measurements were performed.

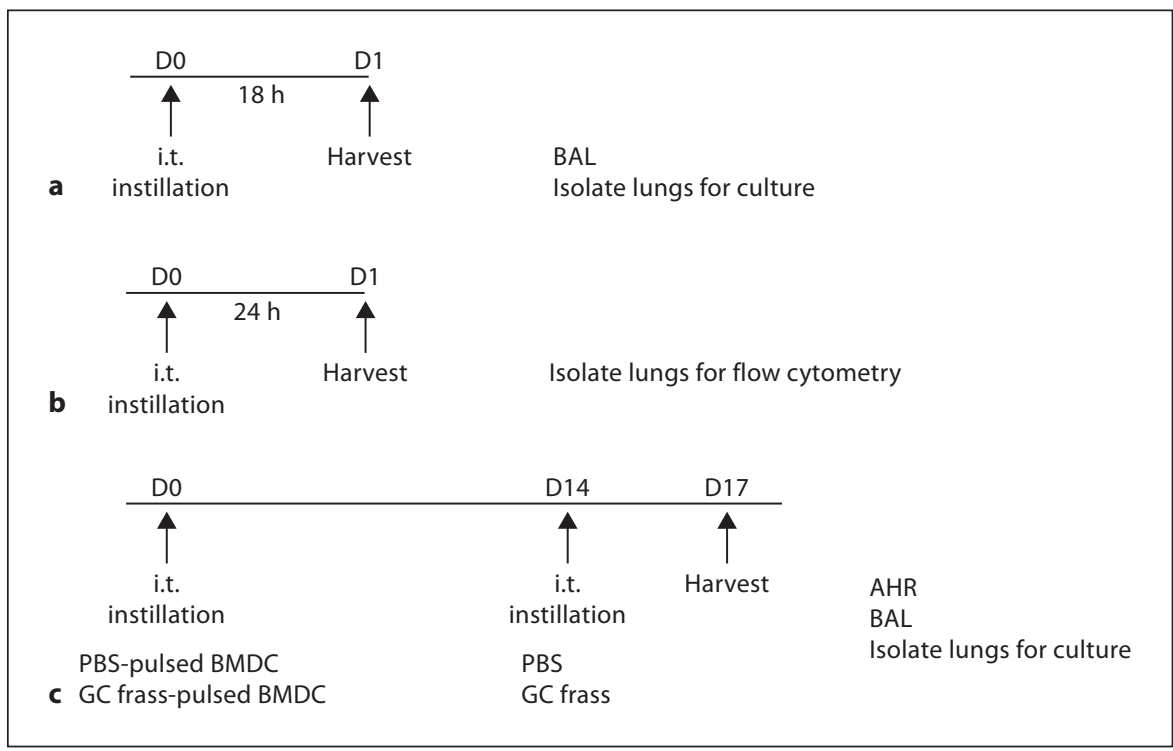

\section{Results}

\section{GC Frass Induced DC Chemokine Expression}

To determine if a single exposure to GC frass was sufficient to induce the expression of chemokines and cytokines important in DC recruitment and proliferation, we exposed naïve mice to GC frass and measured CCL20, MIP- $1 \alpha$, GM-CSF and G-CSF levels in the BAL fluid $18 \mathrm{~h}$ after instillation. Compared to PBS-treated mice, exposure to GC frass significantly induced the DC-attracting chemokines CCL20 (fig. 2a) and MIP-1 $\alpha$ (fig. 2b) in the BAL fluid. In addition, GM-CSF and G-CSF, both of which are important for DC differentiation were significantly increased following exposure to GC frass (fig. 2c, d). These data suggest that GC frass can induce the release of chemokines responsible for the recruitment and proliferation of DCs.

\section{GC Frass Induced DC Recruitment into the Airways and Upregulation of Co-Stimulatory Molecule Expression}

To test whether a single exposure to GC frass could induce DC migration, we quantified pulmonary mDCs and $\mathrm{pDCs} 18 \mathrm{~h}$ following GC frass exposure. We classified

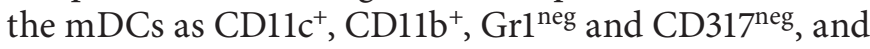
the pDCs as $\mathrm{CD} 11 \mathrm{c}^{+}, \mathrm{CD} 11 \mathrm{~b}^{\text {neg }}, \mathrm{Gr} 1^{\text {low }}$ and $\mathrm{CD} 317^{+}$ (fig. 3a). Exposure to GC frass led to an increased number and overall frequency of pulmonary $\mathrm{mDCs}$ in the lung (fig. 3b, c). There was no change in either the total number (fig. 3d) or percentage (fig. 3e) of pDCs in the lung follow- ing GC frass exposure. Consistent with the in vivo chemokine data, these data show that a single exposure to GC frass induced the preferential recruitment of mDCs into the airways of mice.

Next, we investigated the regulation of the co-stimulatory molecules CD80 and CD86 on the lung $\mathrm{mDC}$ and pDC population following GC frass instillation. GC frass exposure significantly induced the number of CD86 and CD80 molecules (as indicated by mean fluorescence intensity) on the surface of $\mathrm{mDCs}$, as well as increased the proportion of CD86- and CD80-expressing mDCs (table 1) demonstrating activation and maturation of these cells. While GC frass increased the number of CD86 molecules on $\mathrm{pDCs}$, the activation of $\mathrm{pDCs}$ was not robust since the percentage of CD86-positive pDCs or the expression of CD80 (mean fluorescence intensity and percentage) were not altered. These data indicate that a single exposure to GC frass upregulated the amount and activation of mDCs in the lung, while having little effect on pDCs.

\section{GC Frass Directly Activated Cytokine Production from DCs}

To determine if GC frass could directly activate DCs, we generated BMDCs by culturing bone marrow cells in the presence of GM-CSF for 6 days. At the end of the culture, these cells were over $95 \% \mathrm{mDC}$ as characterized by flow cytometry $\left(\mathrm{CD} 11 \mathrm{c}^{+}, \mathrm{CD}_{11} \mathrm{~b}^{+}, \mathrm{Gr} 1^{\text {neg }}, \mathrm{CD} 317^{\text {neg; }}\right.$; data not shown). BMDCs were treated ex vivo with GC frass $(1 \mu \mathrm{g} / \mathrm{ml})$ for $18 \mathrm{~h}$ and cytokine expression was measured 
Fig. 2. A single exposure to GC frass induced DC chemokine release from resident airway cells. Naïve mice were administered a single intratracheal instillation of PBS $(40 \mu \mathrm{l})$ or GC frass $(40 \mu \mathrm{g} / 40 \mu \mathrm{l})$ and BAL fluid was harvested $18 \mathrm{~h}$ later and analyzed by ELISA. In all cases, means \pm SEM are reported for each chemokine in $\mathrm{pg} / \mathrm{ml}$ ( $\mathrm{n}=8$ mice per group) and statistical analysis was performed by ANOVA. a CCL20 (* $\mathrm{p}<0.001)$. b MIP-1 $\alpha\left({ }^{*} \mathrm{p}<\right.$ 0.001). c GM-CSF $(* \mathrm{p}=0.003)$. d G-CSF $\left({ }^{*} \mathrm{p}=0.003\right)$.

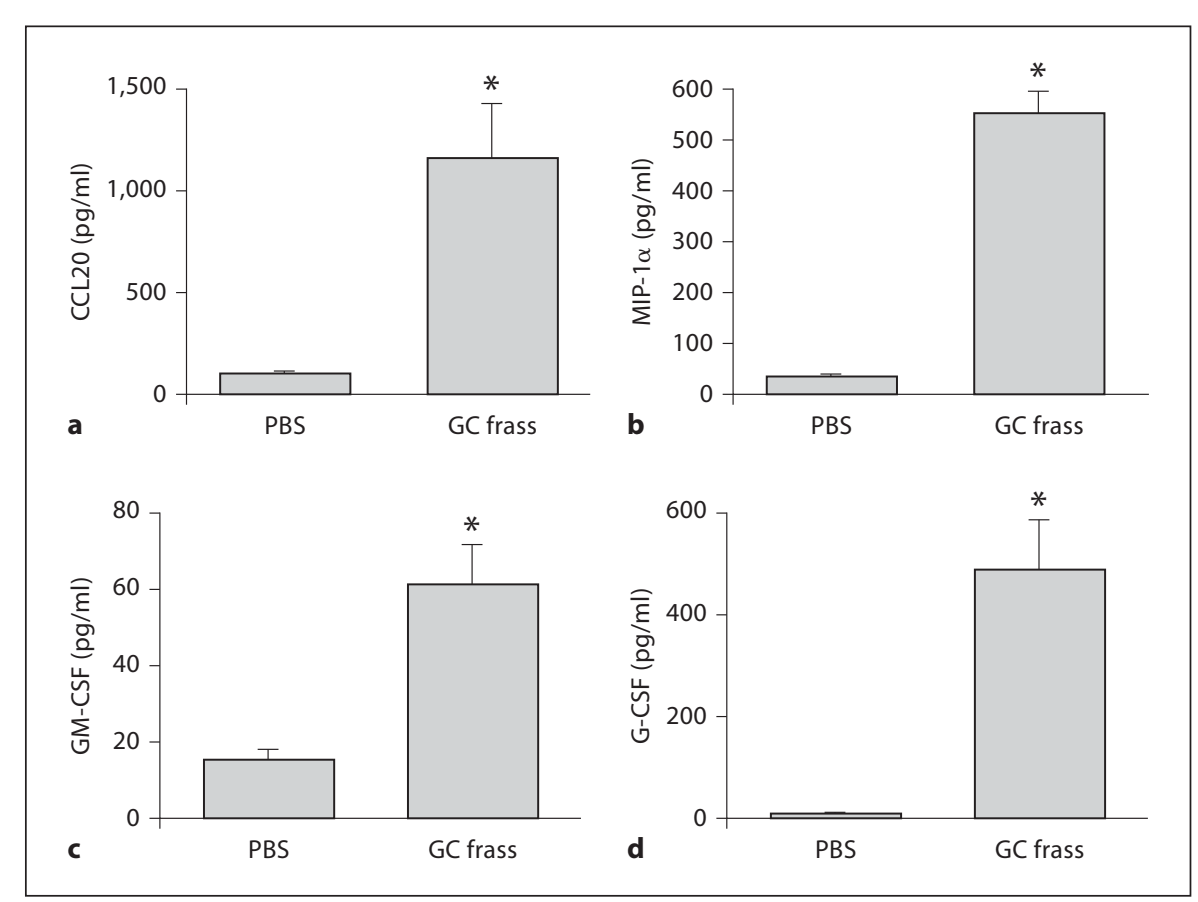

by ELISA. Exposure to GC frass induced a significant release of IL-6 (fig. 4a) and IL-23 (fig. 4b) from DCs, which could potentially lead to Th17-skewing response. IL12p70, which skews towards a Th1 response, was also increased following GC frass treatment (fig. 4c); however, these levels were quite low and were dwarfed in comparison to the release of IL-6. IL-10 levels were below the level of detection (data not shown). These data confirm that GC frass can directly activate BMDCs to synthesize and secrete $\mathrm{T}$ cell-skewing cytokines, and GC frass significantly induces IL-6 and IL-23 expression.

\section{GC Frass Induced Th Cell Cytokine Production}

To determine the cytokine milieu in the lung following a single exposure to GC frass, we isolated the lungs from PBS and GC frass-exposed mice $18 \mathrm{~h}$ after instillation. The lungs were digested and cultured in media for an additional $24 \mathrm{~h}$ in the absence of additional stimuli as a way to determine what the cells are secreting following a single allergen exposure. Th1 cytokine (IFN- $\gamma$ and IL12p70), Th2 cytokine (IL-4, IL-5 and IL-13), and Th17 cytokine (IL-6, IL-23 and IL-17A) levels in the whole lung were measured by ELISA. GC frass induced a significant increase in IL-5 (fig. 5a), IL-17A (fig. 5b) and IL-6 (fig. 5c), suggesting a skewing towards a mixed Th2/Th17 phenotype. The levels of IL-12p70, IL-4 and IL-13 were below thelevels of detection. There was a trend toward increased
Table 1. Co-stimulatory molecule expression on pulmonary DC populations following allergen exposure

\begin{tabular}{|c|c|c|c|c|}
\hline \multirow[t]{2}{*}{ Treatment } & \multicolumn{2}{|l|}{$\mathrm{mDC}$} & \multicolumn{2}{|l|}{$\mathrm{pDC}$} \\
\hline & $\begin{array}{l}\text { CD80 } \\
\text { MFI }\end{array}$ & $\begin{array}{l}\text { CD80 Freq } \\
\text { of parent }\end{array}$ & $\begin{array}{l}\text { CD80 } \\
\text { MFI }\end{array}$ & $\begin{array}{l}\text { CD80 Freq } \\
\text { of parent }\end{array}$ \\
\hline PBS & $208 \pm 12$ & $4.1 \pm 0.6$ & $199 \pm 21$ & $6.1 \pm 0.4$ \\
\hline GC frass & $1,128 \pm 60$ & $38.5 \pm 3.3$ & $194 \pm 41$ & $6.7 \pm 0.6$ \\
\hline $\mathrm{p}$ value & $<0.001$ & $<0.001$ & ns & ns \\
\hline \multirow[t]{3}{*}{ Treatment } & \multicolumn{2}{|l|}{$\mathrm{mDC}$} & \multicolumn{2}{|l|}{$\mathrm{pDC}$} \\
\hline & CD86 & CD86 Freq & CD86 & CD86 Freq \\
\hline & MFI & of parent & MFI & of parent \\
\hline PBS & $480 \pm 3$ & $10.6 \pm 0.6$ & $188 \pm 29$ & $7.2 \pm 1.3$ \\
\hline GC frass & $1,134 \pm 59$ & $22.7 \pm 1.1$ & $361 \pm 21$ & $8.1 \pm 0.2$ \\
\hline $\mathrm{p}$ value & $<0.001$ & $<0.001$ & 0.007 & ns \\
\hline
\end{tabular}

Naïve mice were administered a single intratracheal inhalation of PBS $(40 \mu \mathrm{l})$ or GC frass $(40 \mu \mathrm{g} / 40 \mu \mathrm{l})$ and whole lungs were isolated $24 \mathrm{~h}$ later. Cells were dissociated from the lungs, and

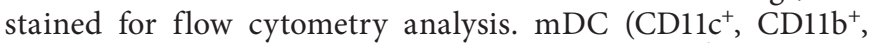
$\left.\mathrm{Gr}^{\text {neg }}, \mathrm{CD} 317^{\text {neg }}\right)$ and $\mathrm{pDC}\left(\mathrm{CD} 11 \mathrm{c}^{+}, \mathrm{CD}_{11 b^{\text {neg }}}, \mathrm{Gr}^{\text {low }}, \mathrm{CD} 317^{+}\right)$ populations were analyzed for CD86 and CD80 expression. Mean fluorescent intensity (MFI) and percentage of cells expressing the co-stimulatory molecules are shown. Values are means \pm SEM, $\mathrm{n}=8 \mathrm{mice} / \mathrm{group}$ and statistical analysis was performed by ANOVA. 
Fig. 3. DC subsets in the lungs following mucosal exposure to PBS. Naïve mice were administered a single intratracheal instillation of PBS $(40 \mu \mathrm{l})$ or GC frass $(40 \mu \mathrm{g} / 40$ $\mu \mathrm{l})$ and whole lungs were isolated $24 \mathrm{~h}$ later. Cells were dissociated from the lungs and stained for flow cytometry analysis. a A representative flow cytometry plot showing the characterization of $\mathrm{mDCs}$ $\left(\mathrm{CD} 11 \mathrm{c}^{+}, \mathrm{CD}_{11 b^{+}}, \mathrm{Gr} 1^{\text {neg }}, \mathrm{CD} 317^{\text {neg }}\right)$ and pDCs $\left(\mathrm{CD} 11 \mathrm{c}^{+}, \mathrm{CD} 11 \mathrm{~b}^{\text {neg }}, \mathrm{Gr} \mathrm{l}^{\text {low }}, \mathrm{CD} 317^{+}\right)$. b Total mDCs. c Percentage of mDCs. d Total pDCs. e Percentage of pDCs. Values are means \pm SEM, $\mathrm{n}=16$ mice/group; statistical analysis was performed by ANOVA (* $\mathrm{p}<0.001$ vs. PBS).
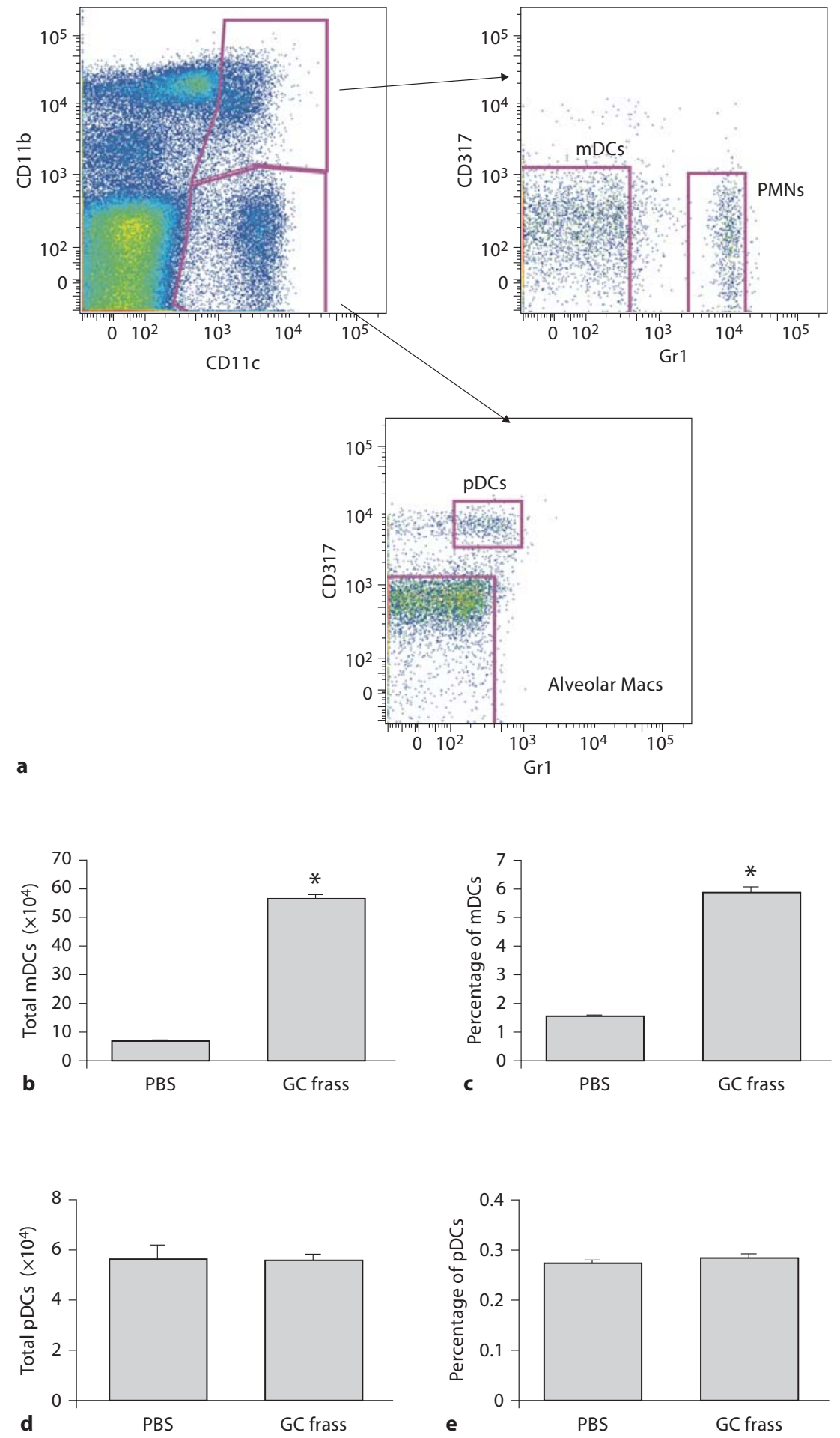


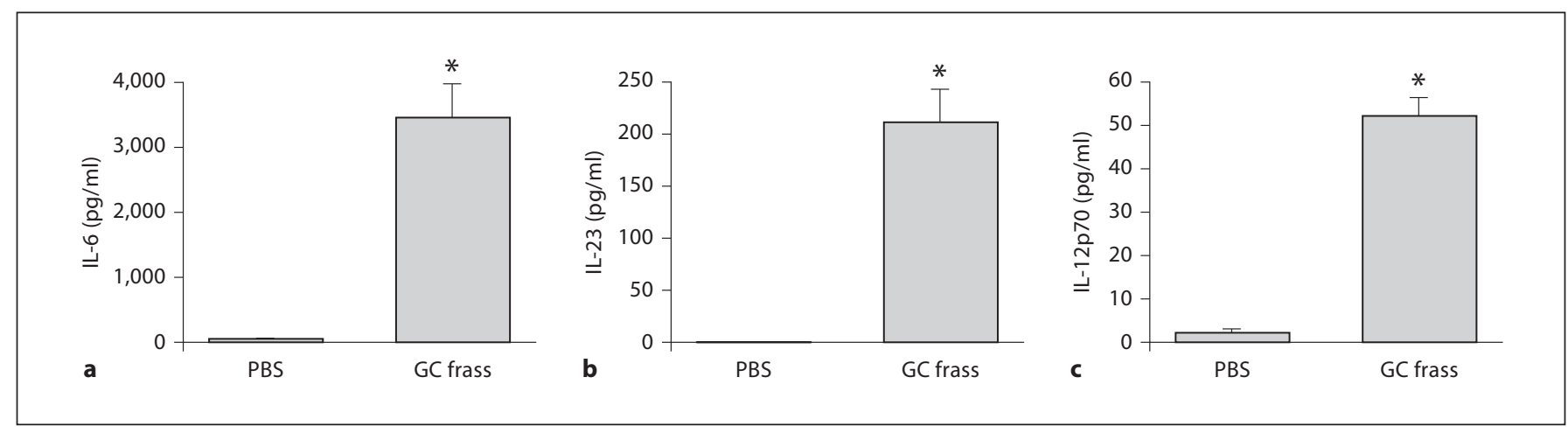

Fig. 4. GC frass-induced BMDC cytokine production. BMDC were cultured in the presence of GM-CSF for 6 days prior to treatment with GC frass $(1 \mu \mathrm{g} / \mathrm{ml}) ; 18 \mathrm{~h}$ later, cell supernatants were collected, clarified and analyzed by ELISA. In all cases, means \pm
SEM are reported for each chemokine in $\mathrm{pg} / \mathrm{ml}(\mathrm{n}=4-6$ experiments) and statistical analysis was performed by ANOVA (* $\mathrm{p}<$ 0.001. a IL-6 levels. b IL-23 levels. c IL-12p70 levels.
Fig. 5. A single exposure to GC frass induced cytokine production in the whole lung. Naïve mice were administered a single intratracheal instillation of PBS $(40 \mu \mathrm{l})$ or GC frass $(40 \mu \mathrm{g} / 40 \mu \mathrm{l})$ and whole lungs were isolated $18 \mathrm{~h}$ later. Cells were dissociated and cultured for an additional $24 \mathrm{~h}$ in the absence of additional stimuli. Cell supernatants were collected, clarified and analyzed by ELISA. In all cases, means \pm SEM are reported for each chemokine in $\mathrm{pg} / \mathrm{ml}$ ( $\mathrm{n}=8 \mathrm{mice} /$ group) and statistical analysis was performed by ANOVA $\left({ }^{*} \mathrm{p}<\right.$ 0.001 vs. PBS). a IL-5 levels. b IL-17A levels. c IL- 6 levels. d IFN- $\gamma$ levels (not significant).

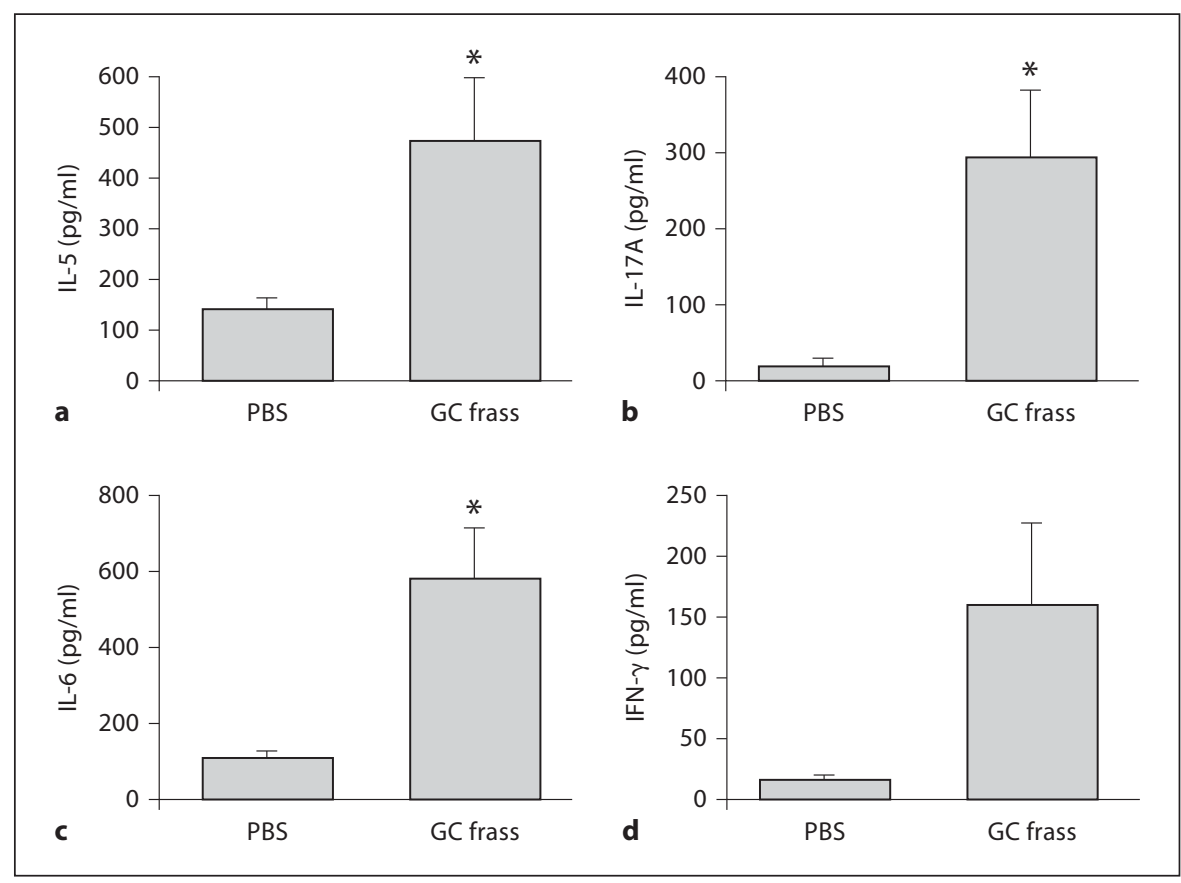

IFN- $\gamma$, however, this did not reach statistical significance (fig. 5d). Together, these data show that a single exposure to GC frass can alter the lung cytokine milieu in a manner that is conducive for an asthma phenotype.

\section{GC Frass-Pulsed DCs Regulate Allergic Airway Inflammation}

To confirm the crucial role for DCs in mediating allergic airway inflammation, we cultured BMDCs for 6 days in the presence of GM-CSF. BMDCs were then treated with PBS or GC frass for $18 \mathrm{~h}$ and adoptively transferred into the lungs of naïve $\mathrm{BALB} / \mathrm{c}$ mice. Fourteen days later, mice were challenged with intratracheal instillation of PBS or GC frass and airway responses were measured $72 \mathrm{~h}$ after challenge. Adoptive transfer of GC frass-exposed BMDCs induced AHR to acetylcholine challenge (fig. 6a). Next, we cultured whole-lung homogenates to assess the ability of GC frass-pulsed BMDCs to induce 
Fig. 6. Adoptive transfer of PBS- or GC frass-pulsed mDCs to naïve mice induced AHR and a Th2/Th17 phenotype. Naïve mice were sensitized with PBS- or GC frass-pulsed BMDC on day 0. Mice were challenged with PBS $(40 \mu \mathrm{l})$ or GC frass $(40 \mu \mathrm{g} / 40 \mu \mathrm{l})$ on day 14 . On day 17 , mice were anesthetized and acetylcholine was injected after establishment of a stable airway pressure. In all cases, means \pm SEM are reported for each chemokine in $\mathrm{pg} / \mathrm{ml}$ ( $\mathrm{n}=8 \mathrm{mice} /$ group) and statistical analysis was performed by ANOVA. a AHR was measured as airway pressure time index (APTI) in $\mathrm{cm} \mathrm{H}_{2} \mathrm{O} \times \mathrm{s}^{-1}$ (compared to PBS, $\left.{ }^{*} \mathrm{p}<0.001\right)$. Lungs from the mice were excised, cells dissociated and maintained in a single suspension culture for 3 days in the presence of ConA $(10 \mu \mathrm{g} / \mathrm{ml})$. Cell supernatants were collected, clarified and analyzed by ELISA. b IL-4 levels (* $\mathrm{p}<0.001$ vs. PBS). c IL-5 levels $\left({ }^{*} \mathrm{p}<\right.$ 0.001 vs. PBS). d IL-13 levels $\left({ }^{*} \mathrm{p}<0.001\right.$ vs. PBS). e IL-17A levels ( ${ }^{*} \mathrm{p}<0.001$ vs. PBS). $\mathbf{f}$ IFN- $\gamma$ levels ( ${ }^{*} \mathrm{p}<0.001$ vs. PBS).

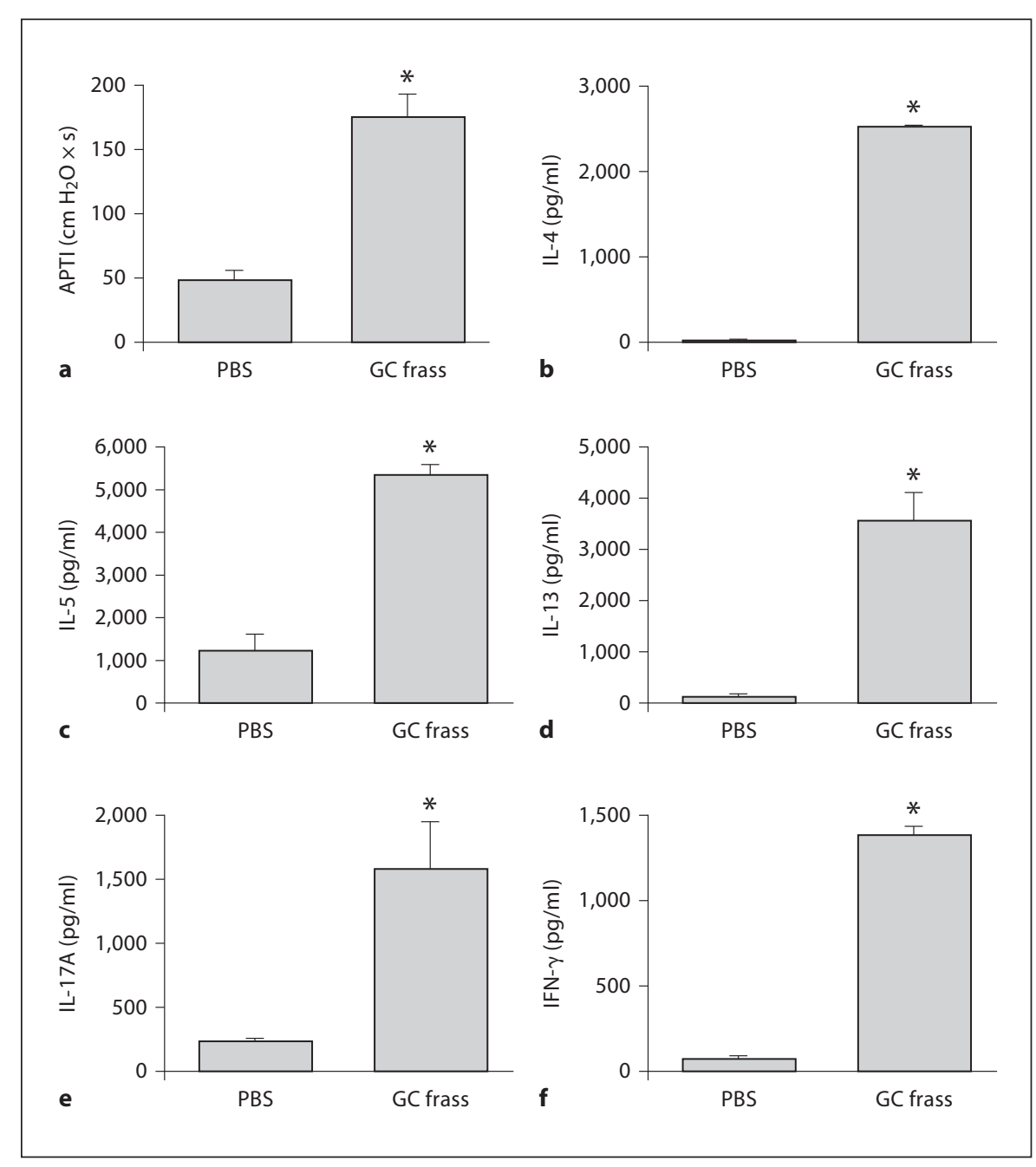

Th2, Th1 and Th17 cytokine production. Adoptive transfer of GC frass-stimulated BMDCs induced Th2-associated cytokines IL-4 (fig. 6b), IL-5 (fig. 6c) and IL-13 (fig. 6d) as well as the Th17-associated cytokine Th17 (fig. 6e). Interestingly, the Th1-associated cytokine IFN- $\gamma$ (fig. 6f) was also significantly increased with exposure to GC frass-pulsed BMDCs. Adoptive transfer of GC frasspulsed mDCs also increased total cellular infiltration as well as the levels of neutrophils, eosinophils and lymphocytes (table 2). Assessment of the airways showed that GC frass-pulsed mDCs were sufficient to induce increased perivascular and peribronchiolar infiltrates into the lung and increase the amount of mucin production as determined by PAS staining (fig. 7). Together, these data suggest that GC frass-pulsed naive mDCs are sufficient to airway inflammation and $\mathrm{T}$ cell skewing in vivo.
MyD88-Deficient BMDCs Do Not Respond to GC Frass Since GC frass contains endotoxin, a TLR4 agonist as well as an agonist of TLR2, we queried the role of TLR activation on DC cytokine production. We isolated BMDC from wild-type and MyD88-deficient mice and measured cytokine production following GC frass exposure. GC frass-induced release of IL-6, IL-23 and IL12 p70 were all abolished in MyD88-deficient BMDCs compared to wild-type BMDCs (fig. 8). These data suggest the importance of TLR engagement, specifically the activation of MyD88 signaling, to the establishment of BMDC cytokine production and skewing towards a Th2/ Th17 cytokine milieu. 

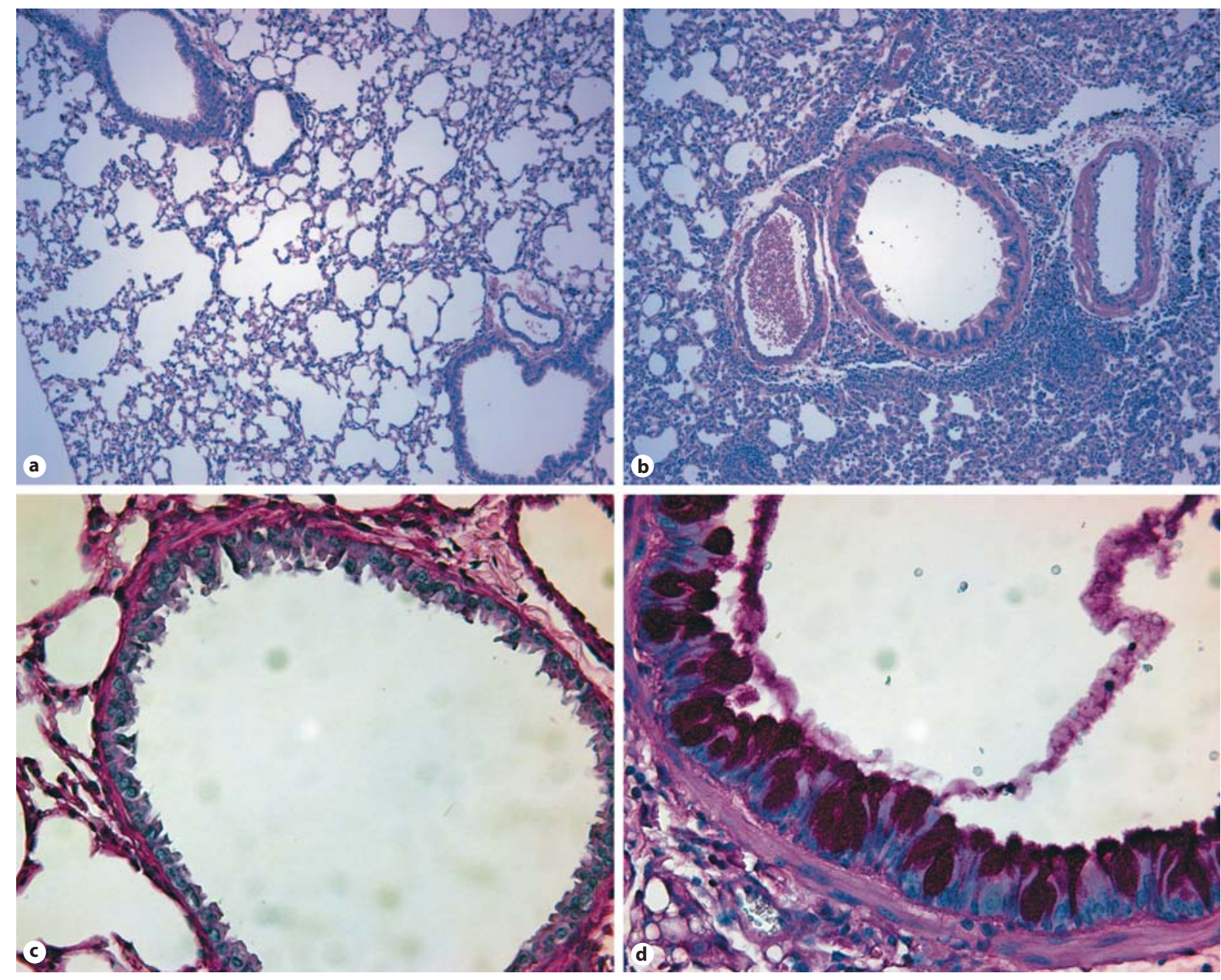

Fig. 7. Histological assessment of lung sections. Naïve mice were sensitized with PBS- or GC frass-pulsed BMDCs on day 0. Mice were challenged with PBS $(40 \mu \mathrm{l})$ or GC frass $(40 \mu \mathrm{g} / 40 \mu \mathrm{l})$ on day 14 . On day 17 , lungs were isolated and fixed in formalin. Hematoxylin and eosin staining of sectioned lungs from PBS-pulsed
BMDC-exposed mice (a) and GC frass-pulsed BMDC-exposed mice (b). PAS staining of sectioned lungs from PBS-pulsed BMDC-exposed mice (c) and GC frass-pulsed BMDC-exposed mice (d). Representative slides are shown of sections from 4 mice per group.

Table 2. Differential cell count in BAL fluid of mice adoptively transferred with mDCs pulsed with PBS or GC frass

\begin{tabular}{lllllr}
\hline & Total cells & Mac & Epi & Neut & Eos \\
\hline PBS-pulsed BMDCs & $20.8 \pm 3.8$ & $15.3 \pm 4.2$ & $2.1 \pm 0.6$ & $2.4 \pm 1.8$ & $0.08 \pm 0.07$ \\
GC frass-pulsed BMDCs & $47.8 \pm 3.7$ & $13.3 \pm 1.6$ & $2.1 \pm 0.1$ & $24.4 \pm 5.7$ & $0.9 \pm 0.3$ \\
p value & 0.043 & ns & ns & 0.011 & $\begin{array}{c}\text { Lymp } \\
\text { ns }\end{array}$ \\
\hline
\end{tabular}

Naïve mice were sensitized with PBS- or GC frass-pulsed BMDCs on day 0 . Mice that received PBS-pulsed BMDCs were challenged with PBS $(40 \mu \mathrm{l})$ and mice that received GC frasspulsed BMDCs were challenged with GC frass $(40 \mu \mathrm{g} / 40 \mu \mathrm{l})$ on day 14 . All mice were sacrificed $72 \mathrm{~h}$ later, BAL fluid was harvest- ed and differential cell counts performed. These data represent 8 mice per group and are expressed as mean \pm SEM cell number $\times 10^{3}$. Statistical significance between GC frass and PBS exposure was determined by ANOVA. 


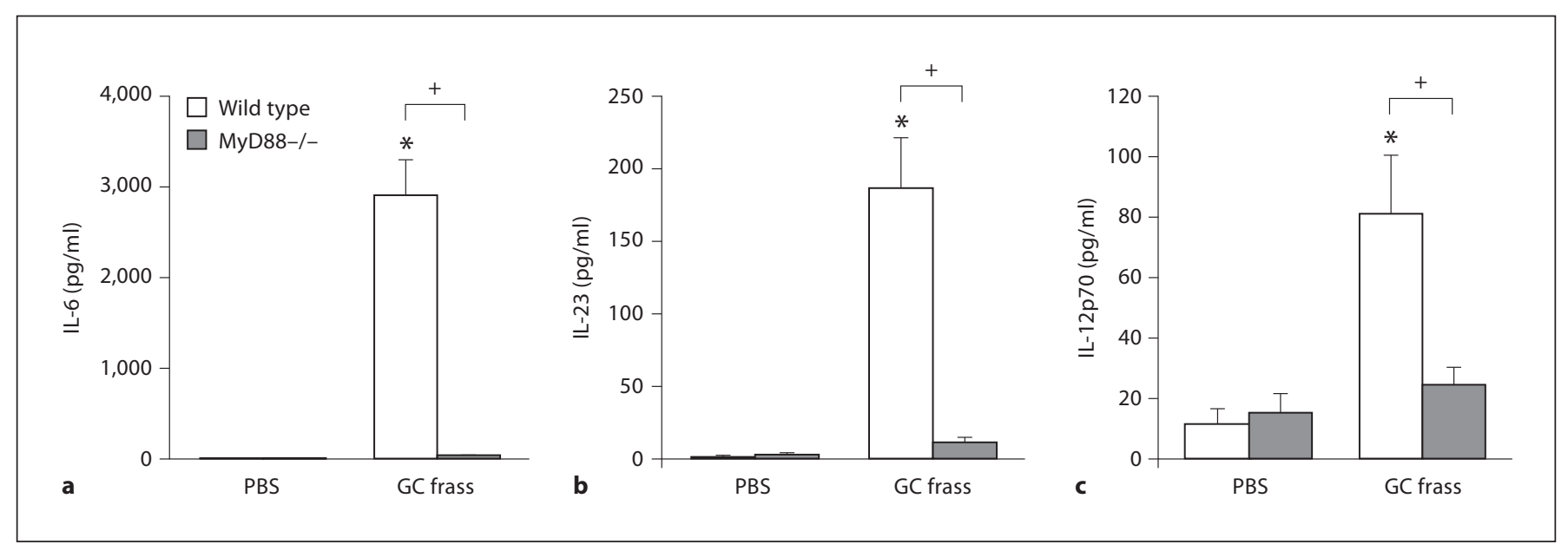

Fig. 8. MyD88-deficient BMDCs do not respond to GC frass. BMDCs from wild-type (C57Bl/6) or MyD88-deficient mice were cultured in the presence of GM-CSF for 6 days prior to treatment with GC frass $(1 \mu \mathrm{g} / \mathrm{ml}) .18 \mathrm{~h}$ later, cell supernatants were collected, clarified and analyzed by ELISA. In all cases, means \pm
SEM are reported for each chemokine in $\mathrm{pg} / \mathrm{ml}(\mathrm{n}=4$ experiments) and statistical analysis was performed by ANOVA. a IL-6 levels ( ${ }^{*} \mathrm{p}<0.001$ vs. PBS; ${ }^{+} \mathrm{p}<0.001$ vs. frass). b IL-23 levels $\left({ }^{*} \mathrm{p}<0.001\right.$ vs. PBS; ${ }^{+} \mathrm{p}<0.001$ vs. frass). c IL-12p70 levels $\left({ }^{*} \mathrm{p}<\right.$ 0.001 vs. PBS; ${ }^{+} \mathrm{p}<0.001$ vs. frass).

\section{Discussion}

In this report, we describe the early response to a single exposure of GC frass and show that GC frass directly activated DC chemokine production in resident airway cells leading to the preferential accumulation of $\mathrm{mDCs}$ into the lungs. In addition, these $\mathrm{mDC}$ s were activated as determined by increased co-stimulatory molecule expression. In the whole-lung cultures, we detected cytokine skewing towards a Th2/Th17 phenotype which occurred within $18 \mathrm{~h}$ of GC frass exposure. We confirmed that GC frass could directly activate BMDCs in vitro by releasing high levels of IL-6, along with increased levels of both IL-23 and IL-12p70. To confirm the importance of DC activation on the initiation of allergic airway disease, we adoptively transferred BMDCs treated ex vivo with GC frass and found that a single exposure of GC frass-treated mDCs was sufficient to induce airway inflammation in naïve mice. Lastly, we present compelling evidence that TLR stimulation is crucial for GC frass-induced BMDC activation since MyD88-deficient BMDCs do not respond to GC frass stimulation. This is important as GC frass has been shown to contain both endotoxin and a TLR2 agonist [6], both of which require a functional MyD88 for signaling. Collectively, these data show that GC frass is sufficient to alter the cytokine/chemokine expression to induce cellular recruitment and al- ter the local cellular milieu within the lung and this is due in part to activation of TLRs.

An early response to GC frass exposure is the significant upregulation of chemokines and cytokines (CCL20, MIP- $1 \alpha$, GM-CSF and G-CSF) involved in DC recruitment and differentiation. Importantly, the fact that these mediators are synthesized by the airway epithelium following allergen exposure implicates the airway epithelium as an initiator of the adaptive immune response. Ambient particulate matter [29] and HDM [30] have been shown to increase CCL20 mRNA and protein secretion from human airway epithelium. GM-CSF and G-CSF release was also shown to be significantly increased in primary human bronchial epithelial cells and epithelial cell lines following HDM exposure [31, 32]. Thus, the chemokine milieu present in the lung following allergen exposure may be set up very rapidly by epithelial cells, hence implicating the importance of the epithelium in shaping the nature of the adaptive immune response.

Classically it was thought that only Th2 cytokines drove allergic airway disease. However, Th17 cells may also contribute to the pathogenesis of T cell-mediated allergic reactions. Our data show that GC frass induced a mixed Th2/Th17 cytokine profile within $18 \mathrm{~h}$ of a single exposure. We have previously shown that GC frass induced significant airway neutrophilia within $18 \mathrm{~h}$ of a single exposure [6], and while we did not quantify the 
amount of IL-17A released by neutrophils, a recent study has confirmed that neutrophils are a significant source of IL-17A [33]. Recent studies have implicated Th17 in allergic asthma. HDM-driven AHR was associated with a mixed Th2/Th17 cytokine profile [18]. Allergic sensitization through the airways was shown to prime Th17 cells to release IL-17 into the airway when challenged with allergen [34]. IL-17 was shown to regulate allergic airway inflammation in mouse models [35-37]. In humans, sputum IL-17A and IL-17F levels have been shown to correlate with AHR $[23,38]$. Thus, it is not surprising that GC frass exposure was sufficient to induce IL-17A in the airways of mice. It is possible that activation of Th17 cells may amplify allergic airway inflammation and that activation of Th17 may not be sufficient to induce asthma, but may be required for increased severity of symptoms.

Interestingly, we found a trend towards increased IFN$\gamma$ levels following a single exposure to GC frass, as well as a significant increase in IFN- $\gamma$ levels in the lung following adoptive transfer of GC frass-pulsed BMDCs and challenge with GC frass. This is in contrast to our other work showing that sensitization and challenge to GC frass lead to decreased IFN- $\gamma$ levels in the lungs $[5,39]$. It is possible that a single exposure of GC frass is sufficient to induce IFN- $\gamma$ but that these levels are not maintained long term. In our previous studies, mice were sensitized and challenged with multiple exposures to GC frass, whereas in the adoptive transfer experiment, the sensitization was to GC frass-pulsed BMDC and there was only a single challenge with GC frass. It is possible that an early increase in Th1 is common and may be suppressed by high levels of Th2 or Th17 cytokines following multiple allergen exposures. This concept is supported by a recent study showing that ragweed extract concurrently upregulated Th1-associated genes with Th2-associated genes and the authors propose that allergen-induced airway inflammation is activated by both Th1 and Th2 gene regulation [40]. They argue that an unopposed Th1 gene upregulation would resolve allergic airway inflammation. In our current studies, we find that sensitization of naïve mice with GC frass-pulsed BMDCs induced a Th1/ Th2/Th17 profile of cytokines in the lung.

GC frass exposure resulted in an increased percentage of $\mathrm{mDCs}$ and no change in the percentage of pDCs in the lung. This would suggest that GC frass can trigger the preferential recruitment or proliferation of the subtype of DCs important in the promotion of asthma. In this report, we did not study the proliferation of resident lung DCs, but others have shown that GM-CSF suppressed the development of pDCs [41], while increasing the prolifera- tion of mDCs. mDCs can induce a variety of $\mathrm{T}$ cell response (Th1, Th2, Th17) depending on where they are isolated and what stimuli they received $[42,43]$, while pDC can induce Th1, Th2 or regulatory T cell development depending on the stimulus $[44,45]$. Our recent work revealed that susceptibility to AHR was associated with $\mathrm{mDC}$ allergen uptake while resistance to allergenderived AHR was associated with pDC allergen uptake [18]. Interestingly, however, in human data, the percentage of $\mathrm{pDC}$ was higher than $\mathrm{mDC}$ following allergen challenge [46, 47]. Thus, further understanding the mechanism by which $\mathrm{mDCs}$ and $\mathrm{pDCs}$ are recruited into the lungs may be of therapeutic potential.

The airway response to GC frass highlights the complex interactions incorporated in the regulation of the inflammatory responses seen in respiratory diseases, particularly asthma. Furthermore, our data suggest that an allergen exposure may influence the maturation of airway mucosal DCs and also provides a potential mechanism by which airway epithelial cells may directly affect the dynamics of the DCs. Finally, the evidence presented here provides compelling evidence for the role of the innate immune response in the development of the adaptive Th2 immune response. Further understanding of the complexity of the allergen and its interaction with the respiratory mucosa will help to further elucidate the molecular interplay between airway epithelial cells and DCs.

\section{Acknowledgements}

We thank Dr. Gary Bennett for providing the GC frass and Dr. Shizuo Akira for providing the MyD $88^{-/-}$mice. This work was supported by the National Institutes of Health grant HL075568 (K.P.) and an AMA Seed Research Grant (S.B.D.). It was partially supported by NIH grant AR47363 for the flow cytometry core at Cincinnati Children's Hospital Medical Center.

References

1 Pollart SM, Smith TF, Morris EC, Gelber LE, Platts-Mills TA, Chapman MD: Environmental exposure to cockroach allergens: analysis with monoclonal antibody-based enzyme immunoassays. J Allergy Clin Immunol 1991;87:505-510.

-2 Gelber LE, Seltzer LH, Bouzoukis JK, Pollart SM, Chapman MD, Platts-Mills TA: Sensitization and exposure to indoor allergens as risk factors for asthma patients presenting to hospital. Am Rev Respir Dis 1993; 147:573587. 
3 Rosenstreich DL, Eggleston P, Kattan M, 15 Kohrgruber N, Halanek N, Gröger M, WinBaker D, Slavin RG, Gergen P, Mitchell H, McNiff-Mortimer K, Lynn H, Ownby D, et al: The role of cockroach allergy and exposure to cockroach allergen is causing morbidity among inner city children with asthma. New Engl J Med 1997;336:1356-1363.

4 Sporik R, Squillace SP, Ingram JM, Rakes G, Honsinger RW, Platts-Mills TA: Mite, cat, and cockroach exposure, allergen sensitisation, and asthma in children: a case-control study of three schools. Thorax 1999;54:675-680.

5 Page K, Lierl K, Herman N, Wills-Karp M: Differences in susceptibility to German cockroach frass and its associated proteases in induced allergic inflammation in mice. Respir Res 2007;8:91.

6 Page K, Lierl KM, Hughes VS, Zhou P, Ledford JR, Wills-Karp M: TLR2-mediated activation of neutrophils in response to German cockroach frass. J Immunol 2008;180:63176324.

7 Day SB, Zhou P, Ledford JR, Page K: German cockroach frass proteases modulate the innate immune response via activation of protease-activated receptor-2. J Innate Immun 2010;2:495-504.

8 Holt PG, Schon-Hegrad MA, Oliver J, Holt BJ, McMenamin PG: A contiguous network of dendritic antigen-presenting cells within the respiratory epithelium. Inter Arch Allergy Appl Immunol 1990;91:155-159.

$\checkmark 9$ Charbonnier AS, Kohrgruber N, Kriehuber E, Stingl G, Rot A, Maurer D: Macrophage inflammatory protein $3 \alpha$ is involved in the constitutive trafficking of epidermal Langerhans cells. J Exp Med 1999;190:1755-1768.

10 Weckmann M, Collison A, Simpson JL, Kopp MV, Wark PA, Smyth MJ, Yagita H, Matthaei KI, Hansbro N, Whitehead B, et al: Critical link between TRAIL and CCL20 for the activation of TH2 cells and the expression of allergic airway disease. Nat Med 2007; 13:1308-1315.

-11 Jahnsen FL, Moloney ED, Hogan T, Upham JW, Burke CM, Holt PG: Rapid dendritic cell recruitment to the bronchial mucosa of patients with atopic asthma in response to local allergen challenge. Thorax 2001;56:823-826.

$\checkmark 12$ Cates EC, Fattouh R, Wattie J, Inman MD, Goncharova S, Coyle AJ, Gutierrez-Ramos JC, Jordana M: Intranasal exposure of mice to house dust mite elicits allergic airway inflammation via a GM-CSF-mediated mechanism. J Immunol 2004;173:6384-6392.

$\checkmark 13$ Romani N, Gruner S, Brang D, Kampgen E, Lenz A, Trockenbacher B, Konwalinka G, Fritsch PO, Steinman RM, Schuler G: Proliferating dendritic cell progenitors in human blood. J Exp Med 1994;180:83-93.

-14 Cella M, Scheidegger D, Palmer-Lehmann K, 26 Lane P, Lanzavecchia A, Alber G: Ligation of $\mathrm{CD} 40$ on dendritic cells triggers production of high levels of interleukin-12 and enhances T cell stimulatory capacity: T-T help via APC activation. J Exp Med 1996;184:747-752. ter D, Rappersberger K, Schmitt-Egenolf M, Stingl G, Maurer D: Survival, maturation, and function of CD11c- and CD11c+ peripheral blood dendritic cells are differentially regulated by cytokines. J Immunol 1999;163: 3250-3259.

16 Cella M, Jarrossay D, Facchetti F, Alebardi O, Nakajima H, Lanzavecchia A, Colonna M: Plasmacytoid monocytes migrate to inflamed lymph nodes and produce large amounts of type I interferon. Nat Med 1999; 5:919-923.

17 Kool M, van Nimwegen M, Willart MA, Muskens F, Boon L, Smit JJ, Coyle A, Clausen $\mathrm{BE}$, Hoogsteden HC, Lambrecht BN, et al: An anti-inflammatory role for plasmacytoid dendritic cells in allergic airway inflammation. J Immunol 2009; 183:1074-1082.

18 Lewkowich IP, Lajoie S, Clark JR, Herman NS, Spoles AA, Wills-Karp M: Allergen uptake, activation, and IL-23 production by pulmonary myeloid DCs drives ariway hyperresponsiveness in asthma-susceptible mice. PLoS One 2008;3:e3879.

19 Rincón M, Anguita J, Nakamura T, Fikrig E, Flavell RA: Interleukin (IL)-6 directs the differentiation of IL-4-producing CD4+ T cells. J Exp Med 1997;185:461-469.

20 Veldhoen M, Hocking RJ, Atkins CJ, Locksley RM, Stockinger B: TGF $\beta$ in the context of an inflammatory cytokine milieu supports de novo differentiation of IL-17-producing T cells. Immunity 2006;24:179-189.

21 Bettelli E, Carrier Y, Gao W, Korn T, Strom TB, Oukka M, Weiner HL, Kuchroo VK: Reciprocal developmental pathways for the generation of pathogenic effector TH17 and regulatory T cells. Nature 2006;441:235-238.

-22 Macatonia SE, Hosken NA, Litton M, Vieira P, Hsieh CS, Culpepper JA, Wysocka M, Trinchieri G, Murphy KM, O'Garra A: Dendritic cells produce IL-12 and direct the development of Th1 cells from naive CD4+ T cells. J Immunol 1995;154:5071-5079.

23 Barczyk A, Pierzchala W, Sozañska E: Interleukin-17 in sputum correlates with airway hyperresponsiveness to methacholine. Respir Med 2003;97:726-733.

24 Chakir J, Shannon J, Molet S, Fukakusa M, Elias JA, Laviolette M, Boulet LP, Hamid Q: Airway remodeling-associated mediators in moderate to severe asthma: effect of steroids on TNF- $\beta$, IL-11, IL-17 and type I and type III collagen expression. J Allergy Clin Immunol 2003;111:1293-1298.

25 Takeuchi O, Hoshino K, Akira S: TLR2-deficient and MyD88-deficient mice are highly susceptible to Staphylococcus aureus infection. J Immunol 2000;165:5392-5396.

6 Walters DM, Breysse PN, Wills-Karp M: Ambient urban Baltimore particulate-induced airway hyperresponsiveness and inflammation in mice. Am J Respir Crit Care Med 2001;164:1438-1443.
27 Wills-Karp M, Luyimbazi J, Xu X, Schofield B, Neben TY, Karp CL, Donaldson DD: Interleukin-13: central mediator of allergic asthma. Science 1988;282:2258-2261.

28 Ewart S, Levitt R, Mitzner W: Respiratory system mechanisms in mice measured by end-inflation occlusion. J Appl Physiol 1995; 79:560-566.

29 Reibman J, Hsu Y, Chen LC, Bleck B, Gordon T: Airway epithelial cells release MIP- $3 \alpha /$ CCL20 in response to cytokines and ambient particulate matter. Am J Respir Cell Mol Biol 2003;28:648-654.

30 Nathan AT, Peterson EA, Chakir J, WillsKarp M: Innate immune responses of airway epithelium to house dust mite are mediated through b-glucan-dependent pathways. J Allergy Clin Immunol 2009;123:612-618.

- 31 King C, Brennan S, Thompson PJ, Stewart GA: Dust mite proteolytic allergens induce cytokine release from cultured airway epithelium. J Immunol 1998;161:36453651.

32 Osterlund C, Grönlund H, Polovic N, Sundström S, Gafvelin G, Bucht A: The non-proteolytic house dust mite allergen Der $\mathrm{p} 2$ induce NF- $\kappa \mathrm{B}$ and MAPK dependent activation of bronchial epithelial cells. Clin Exp Allergy 2009;39:1199-1208.

33 Li L, Huang L, Vergis AL, Ye H, Bajwa A, Narayan $\mathrm{V}$, Streiter $\mathrm{RM}$, Rosin $\mathrm{Dl}$, Okusa $\mathrm{MD}$ : IL-17 produced by neutrophils regulates IFN-к-mediated neutrophil migration in mouse kidney ischemia-reperfusion injury. J Clin Invest 2010;120:331-342.

34 Wilson RH, Whitehead GS, Nakano H, Free ME, Kolls JK, Cook DN: Allergic sensitization through the airway primes Th17-dependent neutrophilia and airway hyperresponsiveness. Am J Respir Crit Care Med 2009; 180:720-730.

- 35 Nakae S, Komiyama Y, Nambu A, Sudo K, Iwase M, Homma I, Sekikawa K, Asano M, Iwakura Y: Antigen-specific T cell sensitization is impaired in IL-17-deficient mice, causing suppression of allergic cellular and humoral responses. Immunity 2002; 17:375387.

36 Oda N, Canelos PB, Essayan DM, Plunkett BA, Myers AC, Huang SK: Interleukin-17F induces pulmonary neutrophilia and amplifies antigen-induced allergic response. Am J Respir Crit Care Med 2005;171:12-18.

37 He R, Kim HY, Yoon J, Oyoshi MK, MacGinnitie A, Goya S, Freyschmidt EJ, Bryce P, McKenzie AN, Umetsu DT, et al: Exaggerated IL-17 response to epicutaneous sensitization mediates airway inflammation in the absence of IL-4 and IL-13. J Allergy Clin Immunol 2009;124:761-770.

38 Al-Ramli W, Préfontaine D, Chouiali F, Martin JG, Olivenstein R, Lemière C, Hamid Q: $\mathrm{T}(\mathrm{H}) 17$-associated cytokines (IL-17A and IL-17F) in severe asthma. J Allergy Clin Immunol 2009;123:1185-1187. 
39 Page K, Ledford JR, Zhou P, Wills-Karp M: Mucosal sensitization to German cockroach involves protease-activated receptor-2. Respir Res 2010;11:62.

40 Dharajiya N, Vaidya S, Sinha M, Luxon B, Boldogh I, Sur S: Allergen challenge induces IFN- $\gamma$ dependent GTPases in the lungs as part of a Th1 transcriptome response in a murine model of allergic asthma. PLoS One 2009;4:e8172.

-41 Esashi E, Wang YH, Perng O, Qin XF, Liu YJ, Watowich SS: The signal transducer STAT5 inhibits plasmacytoid dendritic cell development by suppressing transcription factor IRF8. Immunity 2008;28:509-520.
42 Lambrecht BN, DeVeerman M, Coyle AJ, Gutierrez-Ramos JC, Theilemans K, Pauwels RA: Myeloid dendritic cells induce Th2 responses to inhaled antigen, leading to eosinophilic airway inflammation. J Clin Invest 2000;106:551-559.

43 Denning TL, Wang YC, Patel SR, Williams IR, Pulendran B: Lamina propria macrophages and dendritic cells differentially induce regulatory and interleukin 17-producing T cell responses. Nature Immunol 2007; 8:1086-1094.

44 de Heer HJ, Hammad H, Soullié T, Hijdra D, Vos N, Willart MA, Hoogsteden HC, Lambrecht BN: Essential role of lung plasmacytoid dendritic cells in preventing asthmatic reactions to harmless inhaled antigen. J Exp Med 2004;200:89-98.
5 Ito T, Amakawa R, Inaba M, Hori T, Ota M, Nakamura K, Takebayashi M, Miyaji M, Yoshimura T, Inaba K, et al: Plasmacytoid dendritic cells regulate Th cell responses through OX40 ligand and type I IFNs. J Immunol 2004;172:4253-4259.

46 Matsuda H, Suda T, Hashizume H, Yokomura K, Asada K, Suzuki K, Chida K, Nakamura $\mathrm{H}$ : Alteration of balance between myeloid dendritic cells and plasmacytoid dendritic cells in peripheral blood of patients with asthma. Am J Respir Crit Care Med 2002; 166:1050-1054.

47 Bratke K, Lommatzsch M, Julius P, Kuepper M, Kleine HD, Luttmann W, Christian Virchow J: Dendritic cell subsets in human bronchoalveolar lavage fluid after segmental allergen challenge. Thorax 2007;62:168-175. 